\title{
Aluminium stabilization controls organic carbon levels in Chilean volcanic soils
}

\author{
Francisco Matus $^{\mathrm{a}, *}$, Ximena Amigo ${ }^{\mathrm{a}}$, Søren M. Kristiansen ${ }^{\mathrm{b}}$ \\ ${ }^{a}$ Centro Tecnológico de Suelos y Cultivos, Facultad de Ciencias Agrarias, Universidad de Talca, Casilla 747, Talca, Chile \\ ${ }^{\mathrm{b}}$ Department of Agroecology, Danish Institute of Agricultural Sciences, P.O. Box 50, DK-8830 Tjele, Denmark
}

Received 15 December 2004; received in revised form 9 May 2005; accepted 11 May 2005

Available online 28 July 2005

\begin{abstract}
Chilean volcanic soils are known to contain large amounts of organic matter (OM) and amorphous (e.g., allophanic) clay. Here, we test the hypothesis that Al, rather than clay content and climatic conditions, is the most important factor for OM levels in volcanic soils. This was achieved by compiling a total of 225 pedons from two national-wide datasets of south-Central Chilean soils sampled in the first $20 \mathrm{~cm}$ depth. All selected soils are of volcanic origin, previously under native Nothofagusforest and now used as pasture or arable land. The relationships between soil organic $\mathrm{C}$ (from now soil $\mathrm{C}$ ) and environmental and soil characteristics (clay-allophane, Al content) were analysed by simple and multiple linear regression analyses. Soils classify as Alfisols, Andisols, Inceptisols and Ultisols. $\mathrm{Al}$ was extracted by $\mathrm{KCl}\left(\mathrm{Al}_{\mathrm{k}}\right)$, acid ammonium acetate $\left(\mathrm{Al}_{\mathrm{a}}\right)$ and acid ammonium oxalate $\left(\mathrm{Al}_{\mathrm{o}}\right)$. The simple regression models showed that $\mathrm{Al}_{\mathrm{a}}$ correlated best $\left(R^{2}=0.52\right)$ with soil $\mathrm{C}$ variations for the four soil orders studied, while $\mathrm{Al}_{\mathrm{k}}\left(R^{2}=0.08\right)$ and $\mathrm{Al}_{\mathrm{o}}\left(R^{2}=0.17\right)$ were poorly correlated in all soils types. Especially in Inceptisols, $\mathrm{Al}_{\mathrm{a}}$ was highly correlated with soil $\mathrm{C}\left(R^{2}=0.88\right)$. Clay content, and hence allophanic content, was poorly correlated with soil $\mathrm{C}\left(R^{2}=0.14\right)$, as was the mean annual precipitation $\left(R^{2}=0.21\right)$ and temperature $\left(R^{2}=0.15\right)$. These patterns were supported by the multiple regression analyses. Results therefore support the idea that Al is the principal factor for immobilization of $\mathrm{OM}$ in acid volcanic soils. As ammonium acetate extractable $\mathrm{Al}$ at $\mathrm{pH} 4.8$ correlated well with $\mathrm{OM}$, and as this is a rarely used method to interpret pedogenic processes, this extraction method warrants further attention.
\end{abstract}

(C) 2005 Elsevier B.V. All rights reserved.

Keywords: Aluminium; Carbon storage; Acid ammonium acetate; Clay content; Climatic factors; Regional database

\footnotetext{
* Corresponding author. Tel.: +56 71 200223; fax: +56 71 200212.

E-mail address: matus@utalca.cl (F. Matus).
}

\section{Introduction}

In Chile, soils of volcanic origin (Andisols) are known to be very rich in soil organic matter (OM). Andisols contain also considerably amounts of active aluminium and amorphous and poorly crystallized minerals and oxides, which cause their unique char-

0016-7061/\$ - see front matter (C) 2005 Elsevier B.V. All rights reserved. doi:10.1016/j.geoderma.2005.05.005 
acteristics as e.g., low bulk density and high phosphate retention (Shoji et al., 1993). Variation of OM levels in soil depends in general on the interactions between input and decomposition rates, which are controlled by factors as climate, soil properties, drainage and land use. Factors controlling soil OM levels include furthermore various in situ stabilization and destabilization mechanisms slowing down or accelerating turnover rates. For instance, the content of clay and silt-sized particles are used in many turnover models to predict soil OM dynamics. The textural influence probably acts through OM sorption on mineral components, as well as porosity, as the soil structure influences gas exchange, water availability and the transport of solutes. There is also evidence that $\mathrm{Al}$ stabilization influence OM content in some soils types as Al extracted by e.g., pyrophosphate which had been correlated with soil organic $\mathrm{C}$ in volcanic soils (Nanzyo et al., 1993a; Shoji et al., 1993). The stabilizing effect of $\mathrm{Al}$ on soil $\mathrm{OM}$ appears to be due to complexation of $\mathrm{Al}$ in the soil solution and subsequent precipitation of insoluble Al-OM surface complexes, which suppress microbial enzyme activity and substrate degradation rates (Sollins et al., 1996). There may, however, be a confounding effect between Al, clay content and mineralogy in volcanic soils. The clay fraction in many volcanic soils is namely rich in amorphous, Al-rich allophanic material which also may slow down OM decomposition rates (e.g., Parfitt et al., 1999, 2002). However, Aran et al. (2001) showed that non-allophanic Andisols has a strong ability to immobilize soil $\mathrm{C}$, suggesting that amounts of allophanic material per se is not the controlling factor for OM stabilization.

Al-rich volcanic soils consist of a continuum from amorphous to very short range ordered to well-crystalline minerals. Analysis of Al involved in pedogenic processes are traditionally determined by wet chemical reagents such as pyrophosphate, oxalate and dithionite-citrate-bicarbonate (DCB), while other agents are less frequently applied, e.g., ammonium acetate, $\mathrm{CuCl}_{2}, \mathrm{KCl}$ and $\mathrm{NaOH}$ (McLean, 1965; Garcia-Rodeja et al., 2004). However, recently the usefulness of the commonly used extraction agent for organic bound $\mathrm{Al}$, pyrophosphate at $\mathrm{pH} 10$, has been questioned (Kaiser and Zech, 1996). Al extracted by acid oxalate $\left(\mathrm{Al}_{\mathrm{o}}\right)$ is considered to represent the sum of $\mathrm{Al}$ in organic and amorphous complexes, in non-crystalline hydrous oxides and in allophane and imogolite, but generally exceeds Al-extracted by DCB in the same horizon (Parfitt and Childs, 1988). Al extraction by DCB is considered to represent both amorphous and crystallized $\mathrm{Al}$ in most soils, but the exact nature of DCB-extracted Al is not well understood (Parfitt and Childs, 1988). $\mathrm{KCl}$ extracts the $\mathrm{Al}$ from easy exchangeable sites, while acid ammonium acetate may dissolve soluble forms from exchangeable sites (KCl-extractable) plus some OM-complexed $\mathrm{Al}$ and some $\mathrm{Al}(\mathrm{OH})_{3}$ in addition (McLean, 1965). Extraction with acid ammonium acetate is hence not as effective as with acid oxalate solution, but stronger than un-buffered salt as $\mathrm{KCl}$, normally used to determine the exchangeable Al. This makes ammonium acetate an interesting but rarely used agent for studies of pedogenesis in acid soils where Al-OM complexes and poorly crystalline $\mathrm{Al}$-forms are common. Ammonium acetate extraction has accordingly been found by Urbina de Alcayaga (1965) to correlate with soil OM levels of 202 volcanic Chilean soils. This author also found a positive correlation for the average of four group of OM soils versus mean annual precipitation and negative correlation for mean annual temperature. The dataset was originated from the topsoil and profile survey and $\mathrm{Al}$ was analysed by ammonium acetate (cited as Morgan solution).

None of above-mentioned investigations examined the influence of climate and soil properties on a regional base, which allows a comparison of individual and combined effects of $\mathrm{Al}$, texture, mineralogy, and climate on soil $\mathrm{C}$ variation. Such a comparison was done by Percival et al. (2000) who examined the key factors controlling soil $\mathrm{C}$ in New Zealand grassland soils. Al extractable in pyrophosphate, rather than allophane content explained the greatest variation in soil C content, while clay content and climatic factors were poorly correlated with soil C. This suggests that chemical stabilization was the dominant factor controlling soil $\mathrm{C}$ levels in these New Zealand soils.

The aim of this paper was to examine the hypothesis that $\mathrm{Al}$, rather than clay content, clay mineralogy or climatic factors exerts the strongest control on $\mathrm{C}$ content of Chilean volcanic soils, and to compare different $\mathrm{Al}$ extraction methods with respect to $\mathrm{OM}$ stabilisation. This was done by mean of regional databases to facilitate the use of statistical analyses, and comparison of different $\mathrm{Al}$ extraction methods. 


\section{Materials and methods}

\subsection{The soils}

In Chile, large areas of volcanic soils have developed under native Nothofagus forest before clearance by cutting and burning during the 19th century. About 5.1 millions hectares $(60 \%)$ of Chilean agricultural land is derived from volcanic materials (Mella and Kühne, 1985). Now, about $80 \%$ of the landscape under study is used for small-grain cereal or grass pasture (ODEPA, 2004). Fig. 1 shows the soil type distribution and the position of active volcanoes in southern Central Chile. Four orders from the USDA classification (Soil Survey Laboratory Staff, 1996) are represented on these volcanic-derived parent materials: Alfisols, Andisols, Inceptisols and Ultisols. The investigated soils are generally rich in $\mathrm{Al}$ and have $\mathrm{Al}$ : $\mathrm{Si}$ ratios of about 2 (Besoain and Sepúlveda, 1985). Soil C concentration is between 1 and $19 \%$. The mineralogy is dominated by allophanic material, while iron hydroxides and crystalline iron oxides contribute less (Escudey et al., 2004). Soil $\mathrm{pH}$ (water) values are between 4.5 in non-limed and 6.7 in limed soils. Mean annual precipitation varies from 800 to $2750 \mathrm{~mm}$ and mean annual temperature is between 11 to $16{ }^{\circ} \mathrm{C}$ in this part of Chile.

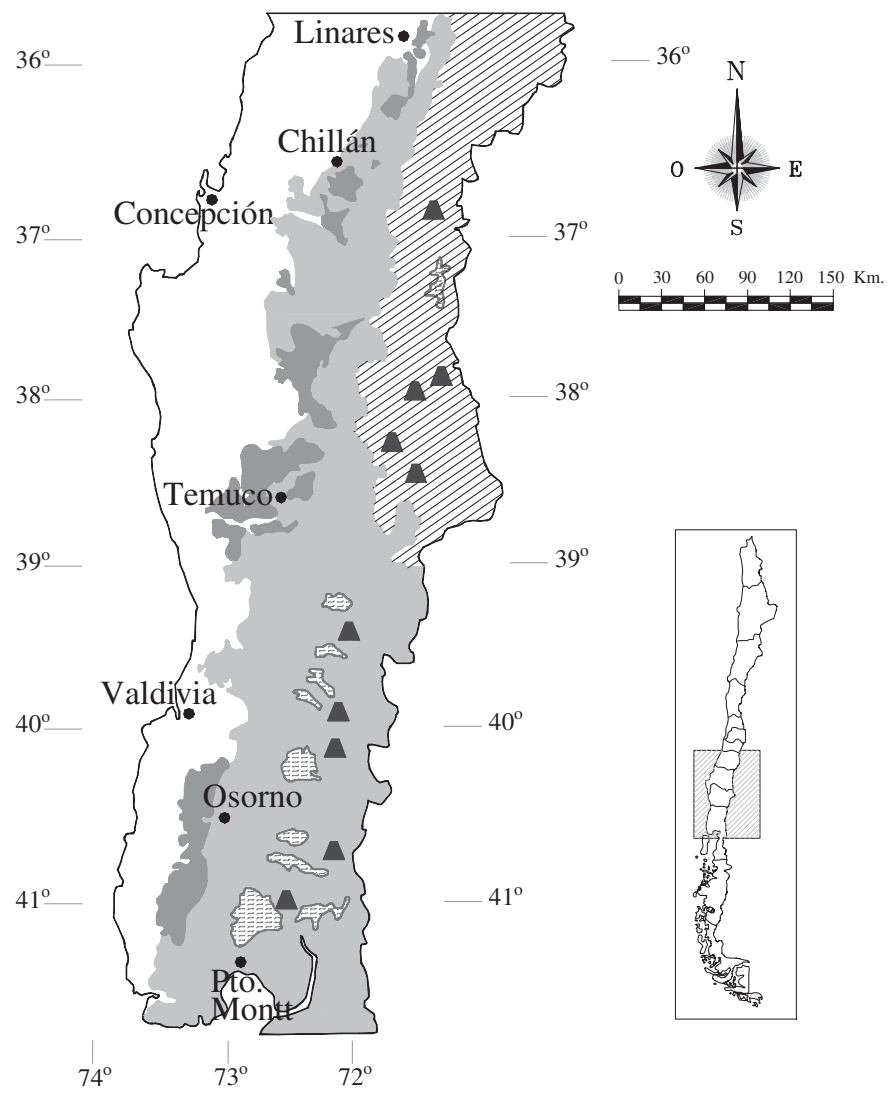

Andisols and Inceptisols

- Volcanoes

Alfisols and Ultisols

High Mountains

Not Volcanic Soils

Lakes

Fig. 1. Distribution of volcanic soils in southern-Central Chile. 


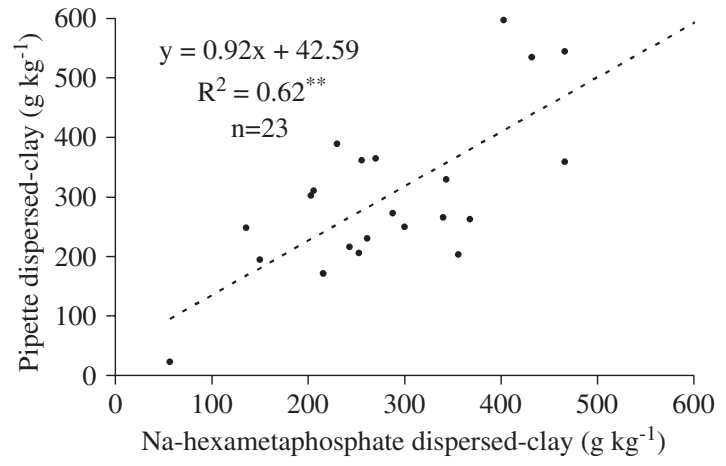

Fig. 2. Concentration of clay from well dispersed materials by pipette method after destruction of organic matter from Mella and Kühne (1985) versus concentration of clay after destruction of organic matter and dispersion with Na-hexametaphosphate from Rodríguez (1993) $(* *=P<0.01)$. All soils come from volcanic origin.

\subsection{Databases}

Two independent databases were used. The first dataset is from soil fertility surveys of $>236$ pedons sampled to a $20 \mathrm{~cm}$ depth throughout the area showed in Fig. 1. These soils were analysed and presented by Rodríguez (1993). This is hereafter denoted Database A. The second dataset was from the "National Chilean database inventory' which contains 237 pedons described in the same area for various purposes (e.g., CIREN, 2001). This database is hereafter denoted Database B. Many described pedons did not contain the complete set of required data (see below), and these were excluded from the analysis. This was mainly due to $\mathrm{Al}$ has not been analysed routinely. A total of 169 pedons from Database A and 56 pedons in Database B were hence selected. After careful inspection of data and laboratory protocols from the two databases, we conclude that our two databases are both comparable and reliable, although more than $50 \%$ of the pedons was not included.

\subsection{Laboratory analysis}

Al was extracted by the following methods: $1 \mathrm{M}$ $\mathrm{KCl}\left(\mathrm{Al}_{\mathrm{k}}\right), 0.2 \mathrm{M}$ ammonium oxalate at $\mathrm{pH} 3.0\left(\mathrm{Al}_{\mathrm{o}}\right)$ (Soil Survey Laboratory Staff, 1996) and $1 \mathrm{M}$ acid ammonium acetate at $\mathrm{pH} 4.8\left(\mathrm{Al}_{\mathrm{a}}\right)($ McLean, 1965). Database $\mathrm{B}$ contained analysis of $\mathrm{Al}_{\mathrm{k}}$ and $\mathrm{Al}_{\mathrm{o}}$, while Database A contained data on $\mathrm{Al}_{\mathrm{a}}$ only. Soil $\mathrm{C}$ was analysed by the Walkley-Black method (Allison, 1965) and bulk density by the clod method (Soil Survey Laboratory Staff, 1996) for both databases. Clay dispersion in Database A was determined by Bouyouco's method from pre-treated samples after destruction of $\mathrm{OM}$ with $\mathrm{H}_{2} \mathrm{O}_{2}$ (Day, 1965). Clay dispersion in Database B was determined by the pipette method also with destruction of $\mathrm{OM}$ with $\mathrm{H}_{2} \mathrm{O}_{2}$ (Soil Survey Laboratory Staff, 1996).

It has been suggested that sodium-hexametaphosphate in allophanic soils does not disperse clay particles completely (Nanzyo et al., 1993b). To test the reliability of our clay data we examined the correlation between clay concentrations after $\mathrm{Na}$-hexametaphosphate dispersion (Bouyouco's method) with clay concentration after complete dispersion (pipette meth-

Table 1

Averages and asymmetry (skewness) of mean annual precipitation (MAP), mean annual temperature (MAT), and amounts per ha of silt, clay, carbon, and ammonium-acetate-extractable $\mathrm{Al}\left(\mathrm{Al}_{\mathrm{a}}\right)$ for the investigated soil orders $(0-20 \mathrm{~cm})$

\begin{tabular}{llclccc}
\hline Soil order & MAP $(\mathrm{mm})$ & MAT $\left({ }^{\circ} \mathrm{C}\right)$ & Silt & Clay & $\mathrm{C}$ & $\mathrm{Al}_{\mathrm{a}}$ \\
\cline { 4 - 6 } & & & & & \\
\hline Alfisol $(n=14)$ & $1377(17)$ & $14.1(0.3)$ & $831(8)$ & $976(103)$ & $60(4)$ & $0.41(0.06)$ \\
$\quad$ Skewness & -1.10 & 1.10 & -0.17 & 0.99 & 1.90 & -0.15 \\
Andisol $(n=126)$ & $1699(35)$ & $13.1(0.1)$ & $618(23)$ & $373(19)$ & $129(5)$ & $1.23(0.06)$ \\
$\quad$ Skewness & 0.59 & 0.64 & -0.27 & 1.41 & -0.03 & 0.96 \\
Inceptisol $(n=14)$ & $1940(164)$ & $11.7(0.1)$ & $606(46)$ & $354(43)$ & $141(15)$ & $1.42(0.17)$ \\
$\quad$ Skewness & -1.60 & 1.60 & -0.63 & -0.37 & -0.15 & -0.08 \\
Ultisol $(n=15)$ & $1262(15)$ & $13.2(0.4)$ & $543(72)$ & $862(56)$ & $81(6)$ & $0.64(0.08)$ \\
$\quad$ Skewness & 0.70 & -0.14 & -0.36 & 0.00 & -0.87 & 0.16 \\
All $(n=169)$ & $1653(32)$ & $13.1(0.1)$ & $628(19)$ & $465(23)$ & $120(3)$ & $1.11(0.05)$ \\
Skewness & 1.58 & 0.57 & -0.40 & 1.40 & 0.22 & 0.99 \\
\hline
\end{tabular}

Data from Database A (Rodríguez, 1993). Standard error of means in brackets. 
Table 2

Averages and asymmetry (skewness) of the amounts of carbon, ammonium oxalate-extractable $\mathrm{Al}\left(\mathrm{Al}_{\mathrm{o}}\right)$, and exchangeable $\mathrm{Al}$ $\left(\mathrm{Al}_{\mathrm{k}}\right)$ for Andisols and Inceptisols per ha $(0-20 \mathrm{~cm})$

\begin{tabular}{llll}
\hline Soil order & $\mathrm{C}$ & $\mathrm{Al}_{\mathrm{o}}$ & $\mathrm{Al}_{\mathrm{k}}$ \\
\cline { 2 - 3 } & $\left(\mathrm{Mg} \mathrm{ha}^{-1}\right)$ & & \\
\hline Andisol $(n=48)$ & $117(5)$ & $38.2(1.8)$ & $0.04(0.07)$ \\
Skewness & 0.35 & -0.79 & 1.50 \\
Inceptisol $(n=8)$ & $69(12)$ & $12.0(2.6)$ & $0.12(0.04)$ \\
$\quad$ Skewness & 1.53 & 0.17 & 0.48 \\
All $(n=56)$ & $110(5)$ & $34.4(2.0)$ & $0.05(0.09)$ \\
Skewness & 0.14 & 0.54 & 1.78 \\
\hline
\end{tabular}

Data from Database B (CIREN, 2001). Standard error of means in brackets.

od) in twenty-three allophanic soils presented in Database A (Mella and Kühne, 1985). In this soils allophanic clay concentration was determined from mineralogical studies by X-ray diffraction (Besoain and Sepúlveda, 1985). This comparison showed that clay content was quite similar in both poor and welldispersed samples (Fig. 2). The average was respectively 300 and $313 \mathrm{~g} \mathrm{~kg}^{-1}$ and there were no significant differences between means $(p>0.05)$. Therefore, we conclude that clay contents is representative in our databases and can safely be correlated with other soil properties.

\subsection{Climatic factors}

Database B were not used for climatic variables since data were uncompleted. Database A was completed for climatic variables by mean annual temperature (MAT) from Mella and Kühne (1985). Mean annual precipitation (MAP) was derived using weather stations spatially distributed in a grid (DGA, 2004). Mean annual precipitation was obtained by overlaying weather stations' locations onto a 15 by $15 \mathrm{~km}$ grid cell in a soil series GIS map $1: 250.000$. Precipitation in each pedon was based on 1969 to 1999 averages from 20 weather stations within a grid cell and soil series map.

\subsection{Conversion of soil properties}

Soil organic $\mathrm{C}$ content $\left(\mathrm{Mg} \mathrm{ha}^{-1}\right)$ was calculated for the top layer $(20 \mathrm{~cm})$ horizon and was based on data for soil $\mathrm{C}$ ( $\mathrm{g} \mathrm{kg}^{-1}$, dry basis), dry bulk density $\left(B, \mathrm{Mg} \mathrm{m}^{-3}\right)$ and horizon thickness $(z, \mathrm{~m})$.

$\mathrm{C}_{\text {mass }}=z \times \mathrm{C} \times B \times 10$

In most studies, the relationship between $\mathrm{C}$ concentration and others properties depends on the weighing of soil $\mathrm{C}$ across horizons. This was the case for Database B $(0-20 \mathrm{~cm})$. For Database A, the $\mathrm{C}$ content depends on both bulk density and $\mathrm{C}$ concentration, since topsoil was sampled to $20 \mathrm{~cm}$ depth. The corresponding mass $\left(\mathrm{Mg} \mathrm{ha}^{-1}\right)$ of $\mathrm{Al}_{\mathrm{o}}, \mathrm{Al}_{\mathrm{a}}, \mathrm{Al}_{\mathrm{k}}$, silt and clay were calculated using a similar approach. Tables 1 and 2 summarize some statistics from the climate and soil properties for each order.

\subsection{Statistical analysis}

We followed a procedure similar to Percival et al. (2000). First, we examined the relationship of soil C content $\left(\mathrm{Mg} \mathrm{ha}^{-1}\right)$ with climatic and soil properties by simple linear regression. Secondly, a multiple regression analysis was carried out to test whether the

Table 3

Coefficient of determination $\left(R^{2}\right)$ of soil organic $\mathrm{C}\left(\mathrm{Mg} \mathrm{ha}^{-1}\right)$ versus mean annual precipitation (MAP), mean annual temperature (MAT), and amounts per ha $(0-20 \mathrm{~cm})$ of silt, clay, and ammonium acetate-extractable $\mathrm{Al}\left(\mathrm{Al}_{\mathrm{a}}\right)$ for the investigated soil orders

\begin{tabular}{|c|c|c|c|c|c|c|}
\hline \multirow[t]{2}{*}{ Soil order } & \multirow[t]{2}{*}{ MAP (mm) } & \multirow[t]{2}{*}{ MAT $\left({ }^{\circ} \mathrm{C}\right)$} & Silt & Clay & $\mathrm{Al}_{\mathrm{a}}$ & \multirow{2}{*}{$\begin{array}{l}\text { Multiple } \\
\text { regression }^{\mathrm{a}}\end{array}$} \\
\hline & & & \multicolumn{3}{|c|}{$\left(\mathrm{Mg} \mathrm{ha}^{-1}\right)$} & \\
\hline Alfisol $(n=14)$ & $0.21^{\mathrm{ns}}$ & $0.21^{\mathrm{ns}}$ & $0.23^{\mathrm{ns}}$ & $0.16^{\mathrm{ns}}$ & $0.65 * * *$ & $0.84 * *$ \\
\hline Andisol $(n=126)$ & $0.09 * * *$ & $0.11^{* * *}$ & $0.03^{\mathrm{ns}}$ & $0.02^{\mathrm{ns}}$ & $0.40 * * *$ & $0.40 * * *$ \\
\hline Inceptisol $(n=14)$ & $0.54 * *$ & $0.53^{* *}$ & $0.00^{\mathrm{ns}}$ & $0.00^{\mathrm{ns}}$ & $0.88 * * *$ & $0.88^{* * *}$ \\
\hline Ultisol $(n=15)$ & $0.50 * *$ & $0.54 * *$ & $0.33^{*}$ & $0.09^{\mathrm{ns}}$ & $0.55^{* *}$ & $0.55^{* *}$ \\
\hline All $(n=169)$ & $0.21 * * *$ & $0.15^{* * *}$ & $0.05^{* *}$ & $0.14 * * *$ & $0.52 * * *$ & $0.55^{* *, \mathrm{~b}}$ \\
\hline
\end{tabular}

n.s. $=$ not significant; $*, * *, * * *=$ significant at $p<0.05, p<0.01, p<0.001$, respectively.

Data from Database A (Rodríguez, 1993).

${ }^{\mathrm{a}} \mathrm{Al}_{\mathrm{a}}$ and MAT were the model parameter for Alfisols, and $\mathrm{Al}_{\mathrm{a}}$ for other soil orders.

${ }^{\text {b }} \mathrm{C}=30.79+49.70 \times \mathrm{Al}_{\mathrm{a}}+0.021 \times \mathrm{MAP}$. 


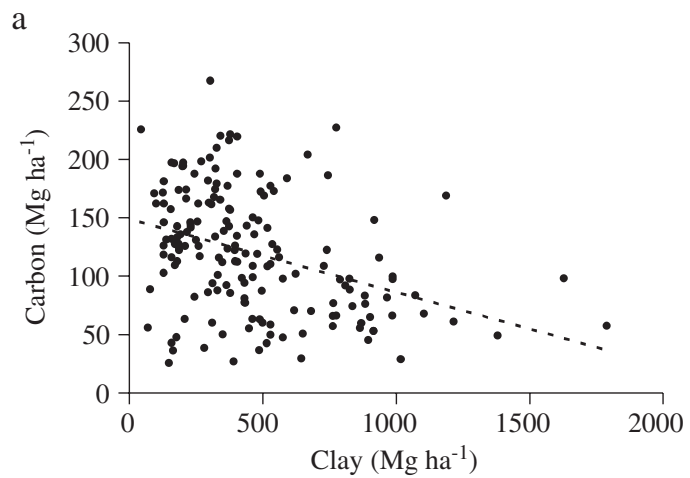

b
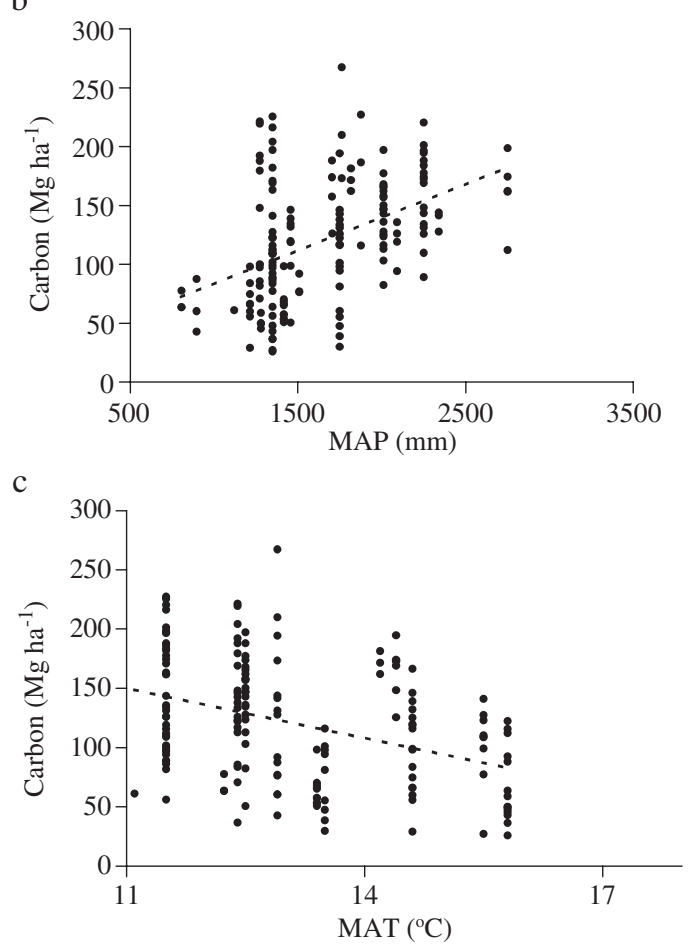

Fig. 3. Relationships from simple regressions between soil organic $\mathrm{C}$ and respectively (a) soil clay content, (b) mean annual precipitation (MAP), and (c) mean annual air temperature (MAT) for the investigated soil orders $(0-20 \mathrm{~cm})$. Data from Database A (Rodríguez, 1993). See Tables 1 and 3 for statistics.

combined effects significantly increased $R^{2}$ values compared with those of simple linear regression. Finally, a quadratic model was used with the six predictors of Burke et al. (1989) as independent variables: mean annual temperature (MAT), mean annual precipitation (MAP) and their squares values $\left(\mathrm{MAT}^{2}\right)$ and $\left(\mathrm{MAP}^{2}\right), \mathrm{MAP} \times$ silt and $\mathrm{MAP} \times$ clay.
Multiple regression analysis enabled us to perform a step-wise history and forward elimination. Mallow's criterion $\left(C_{p}\right)$ was used instead of error mean square, to select the best model. A model was selected when $C_{p}$ approached $p$, the number of parameters in the

a

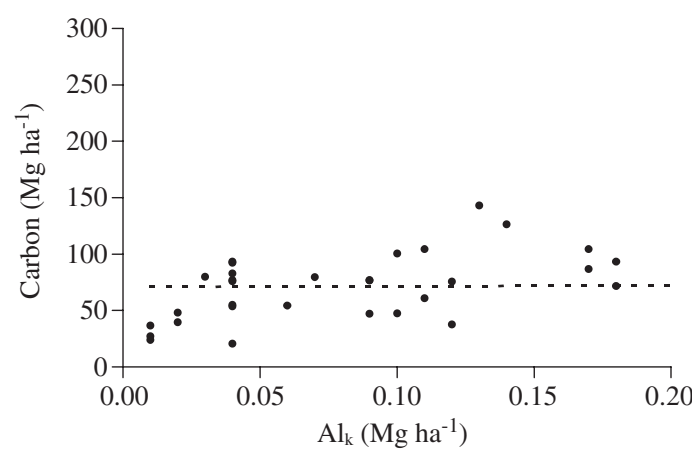

b

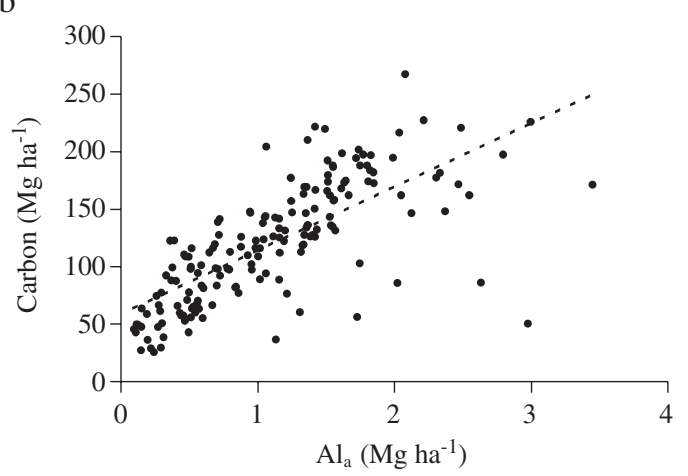

c

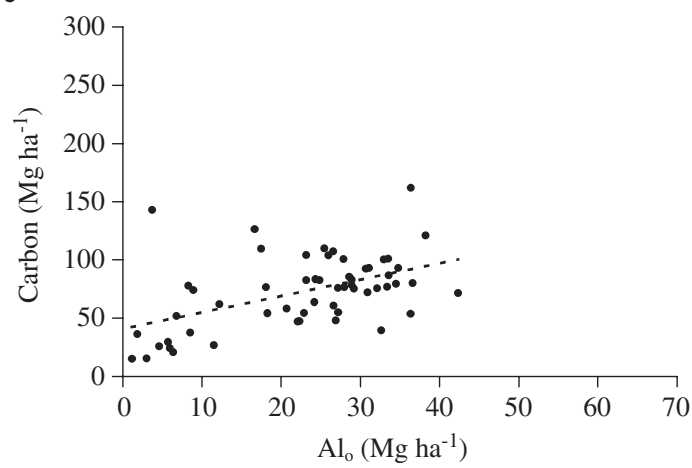

Fig. 4. Relationships from single regressions between soil organic $\mathrm{C}$ and respectively (a) $\mathrm{KCl}$-extractable $\mathrm{Al}\left(\mathrm{Al}_{\mathrm{k}}\right)$, (b) acid ammonium acetate-extractable $\mathrm{Al}\left(\mathrm{Al}_{\mathrm{a}}\right)$ and $(\mathrm{c})$ oxalate-extractable $\mathrm{Al}\left(\mathrm{Al}_{\mathrm{o}}\right)$ for the investigated soil orders $(0-20 \mathrm{~cm})$. Data from Database A (Rodríguez, 1993) and B (CIREN, 2001). See Tables 1-4 for statistics. 
model. All data were tested for normality of the distribution using a Skewness test value of 0.5 (Webster and Oliver, 2001). If the Skewness-value was $>0.5$ we concluded that the distribution was not normal (Tables 1 and 2). Transformation of data did, however, not improve or reduce $R^{2}$, and the regression analysis was hence carried out without data transformation. All analyses were computed using JMP statistical software (SAS Institute, Cary, NC, U.S.A).

\section{Results}

\subsection{Soil organic carbon, clay and silt content}

Soil C ranged from $60 \mathrm{Mg} \mathrm{ha}^{-1}$ for Alfisols in the coast and western Central Valley to $141 \mathrm{Mg} \mathrm{ha}^{-1}$ for Inceptisols in the mountain and eastern Central Valley of Chile (Tables 1 and 2, Fig. 1). Mean clay content ranged from $354 \mathrm{Mg} \mathrm{ha}^{-1}$ for Inceptisols to $976 \mathrm{Mg} \mathrm{ha}^{-1}$ for Alfisols. Silt content was highest in Alfisols (up to $831 \mathrm{Mg} \mathrm{ha}^{-1}$ ), and lowest in Ultisols (543 $\left.\mathrm{Mg} \mathrm{ha}^{-1}\right)$.

Soil C correlated poorly with both clay and silt within each soil order $\left(R^{2}<0.33\right.$, Table 3; Fig. 3a). Silt content explained $<3 \%$ of variation in soil $\mathrm{C}$ in Andisols and Inceptisols, and $<33 \%$ in Ultisols and Alfisol.

\subsection{Climatic variables}

Mean annual precipitation ranged from $1260 \mathrm{~mm}$ for Ultisols to $1940 \mathrm{~mm}$ for Inceptisols, across the same increments as soil C content (Table 1). Differences in MAT between soil orders were small, ranging

Table 4

Coefficient of determination $\left(R^{2}\right)$ of soil organic $\mathrm{C}$ versus oxalateextractable $\mathrm{Al}\left(\mathrm{Al}_{\mathrm{o}}\right)$ and exchangeable $\mathrm{Al}\left(\mathrm{Al}_{\mathrm{k}}\right)$ per ha $(0-20 \mathrm{~cm})$ for Andisols and Inceptisols

\begin{tabular}{lll}
\hline Soil order & $\mathrm{Al}_{\mathrm{k}}$ & $\mathrm{Al}_{\mathrm{o}}$ \\
\cline { 2 - 3 } & $\left(\mathrm{Mg} \mathrm{ha}^{-1}\right)$ & \\
\hline Andisol $(n=48)$ & $0.25^{* *}$ & $0.03^{\mathrm{ns}}$ \\
Inceptisol $(n=8)$ & $0.00^{\mathrm{ns}}$ & $0.18^{\mathrm{ns}}$ \\
All $(n=56)$ & $0.08^{*}$ & $0.17^{* *}$ \\
\hline
\end{tabular}

n.s. $=$ not significant; $*, \quad * *=$ significant at $p<0.05, p<0.01$, respectively.

Data from Database B (CIREN, 2001).

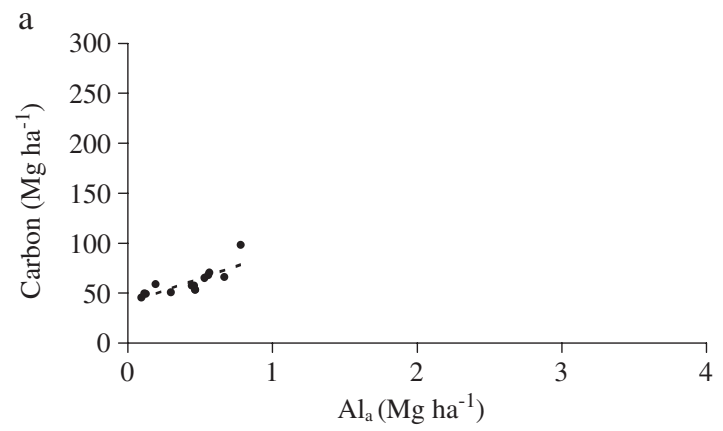

b

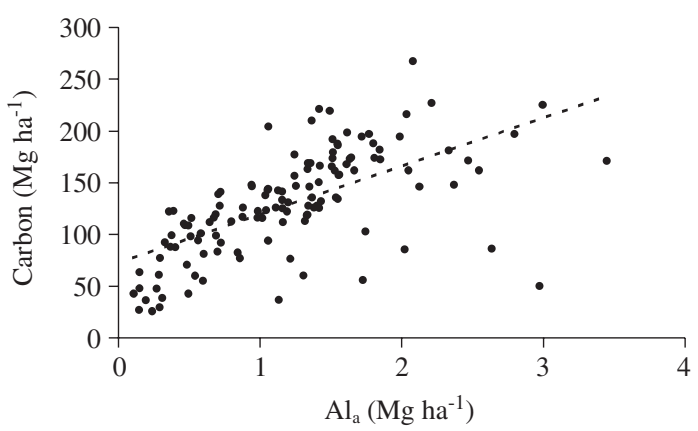

c

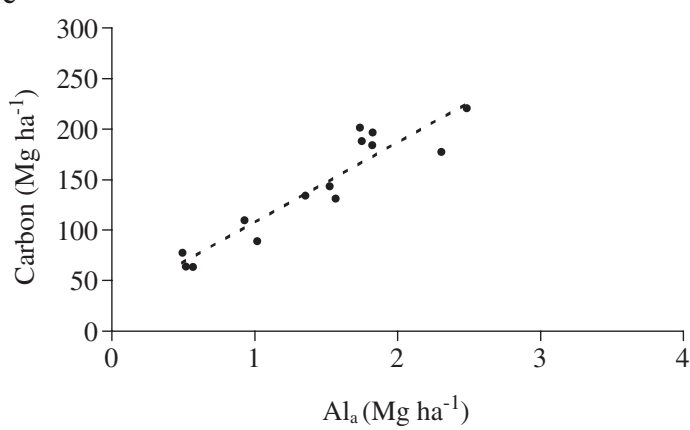

d

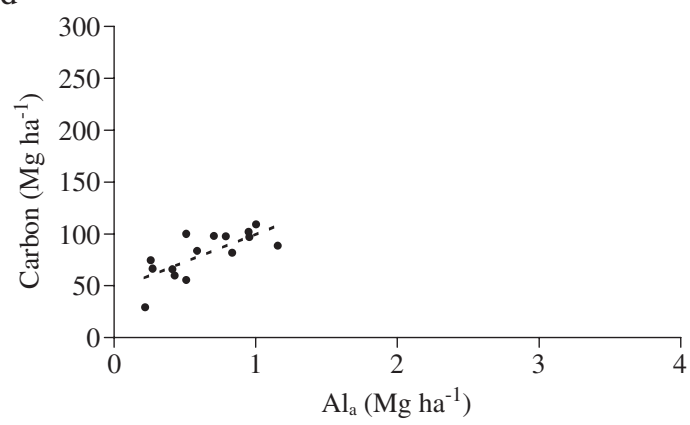

Fig. 5. Relationships from single regressions between soil organic $\mathrm{C}$ and acid ammonium acetate-extractable $\mathrm{Al}\left(\mathrm{Al}_{\mathrm{a}}\right)$ from respectively (a) Alfisols, (b) Andisols, (c) Inceptisols and (d) Ultisols. Data from database A (Rodríguez, 1993). See Tables 1 and 3 for statistics. 
from $11.7{ }^{\circ} \mathrm{C}$ for Inceptisol to $14.1{ }^{\circ} \mathrm{C}$ for the Alfisols. Soil $\mathrm{C}$ content correlated with MAP and MAT across all soils and within each soil order, except for Alfisols (Table 3; Fig. 3b and c). Soil C levels in Andisols showed the poorest relationship with MAP and MAT (Table 3).

\subsection{Aluminium extractable with $\mathrm{KCl}$, acid ammonium acetate, and acid oxalate}

$\mathrm{Al}_{\mathrm{a}}$ data (from Database $\mathrm{A}$ ) ranged from 0.41 to $1.42 \mathrm{Mg} \mathrm{ha}^{-1}$ and Andisols and Inceptisols exhibited the highest mean values (Table 1 ). $\mathrm{Al}_{\mathrm{o}}$ data (from Database $\mathrm{B}$ ) was higher that $\mathrm{Al}_{\mathrm{a}}$ and averaged 38 and $12 \mathrm{Mg} \mathrm{ha}^{-1}$ (Tables 1 and 2). $\mathrm{Al}_{\mathrm{k}}$ (from Database B) ranged between 0.04 and $0.12 \mathrm{Mg} \mathrm{ha}^{-1}$ and were the lowest extractable Al form. Across all orders, soil C content correlated strongly and positively with $\mathrm{Al}_{\mathrm{a}}$, which explained more than half of the soil $\mathrm{C}$ variation, $R^{2}=0.52$ (Table 3; Fig. 4b). The correlation of soil $\mathrm{C}$ with contents of $\mathrm{Al}_{\mathrm{k}}\left(R^{2}=0.08\right)$ and $\mathrm{Al}_{\mathrm{o}}$ $\left(R^{2}=0.17\right)$ were rather poor (Table 4; Fig. $4 \mathrm{a}$ and c). For each of the individual soil order, $\mathrm{Al}_{\mathrm{a}}$ explained the greatest proportion of the soil $\mathrm{C}$ variation, e.g., $>40 \%$ for Andisols and $>55 \%$ for the remaining soil orders (Table 3; Fig. 5[a-d]), while the correlation between soil $\mathrm{C}$ with $\mathrm{Al}_{\mathrm{k}}$ and $\mathrm{Al}_{\mathrm{o}}$ again were the poorest $(<0.25)$ (Table 4$)$.

\subsection{Multiple regression analysis}

The best multiple regression equation selected through Mallow's criterion did not greatly improve the proportion of variation in soil $\mathrm{C}$ content explained by $\mathrm{Al}_{\mathrm{a}}$ in the linear regression. For all soil orders, multiple regressions were significant for both $\mathrm{Al}_{\mathrm{a}}$ and precipitation $\left(R^{2}<0.55, p<0.01\right.$; Table 3$)$. Soil C variation was well explained within each soil order, particularly when temperature was included in the regression model for Alfisols (Table 3).

\section{Discussion}

\subsection{Environmental implications}

Overall, clay content explained little, climatic factors explained more while $\mathrm{Al}$ contents extracted by ammonium acetate explained most of the variation in C content of studied Chilean volcanic soils. It can, however, be argued that the soil $\mathrm{C}$ had not reached a steady state since 19th century clearance of the native Nothofagus-forest, and therefore, that the transition to a new equilibrium could obscure our regression analyses. However, Matus and Rodríguez (1994) estimated by a nitrogen simulation model that the Chilean volcanic soils reached a steady state after 80 years of agriculture. Neither Parfitt et al. (2002) found changes in natural ${ }^{13} \mathrm{C}$ abundance or $\mathrm{C}$ levels in cropped New Zealand volcanic soils 25 years after change to maize cropping; suggesting that the high soil $\mathrm{C}$ levels in an allophanic Andisol was stable. Parfitt et al. (2002) furthermore found similar mineralization rates in Andisols and Inceptisols under different land-uses although $40 \%$ more soil $\mathrm{C}$ in the Andisol was found. This was attributed to sorption sites on Allophane and $\mathrm{Al}$ already being blocked by old C. Our regression analyses was performed on soils previously under intense weathering under the native Nothofagus vegetation and this is thus similar to the New Zealand situation where indigenous forest has been replaced by grasslands. Such ecosystems are known to cause high concentrations of free $\mathrm{Al}$ that form humus complexes, as the natural soil $\mathrm{pH}$ often is below 5 where $\mathrm{Al}-\mathrm{OM}$ complexation is favoured (Adams et al., 2000). As the $\mathrm{pH}$ of the soils today generally is above 5 , the present-day situation is probably in favour of mineral (allophane) formation as $\mathrm{Al}$ is not longer complexed by OM (Adams et al., 2000). The high soil $\mathrm{C}$ levels in our soils are thus probably a result of the native forest ecosystem abandoned $>100$ years ago. These findings hence suggest that soil $\mathrm{C}$ is presently at a high, but steady level in Chilean volcanic soils.

Differences in land-use may also influence our results, because no distinction between grassland and grassland converted to cultivation was made. For instance, Burke et al. (1989) found that C losses when grassland was turned to cultivated soils were constant under simultaneous variation of climate and soil properties. In Chile more than $80 \%$ of the volcanic soils are under similar land-use with improved or unimproved pastures in rotation with cereal crops. We hence assumed that soil $\mathrm{C}$ difference between grassland and cultivated soils followed the same trends by climate and soil variation. More data dispersion could 
be expected due to the different land-uses but the $R^{2}$ from the linear regression were similar to those found by previous studies, e.g., Burke et al. (1989) and Homman et al. (1995). In the work of Burke et al. (1989) a quadratic equation provided the best model and explained $51 \%$ of soil $\mathrm{C}$ variation for grassland and $54 \%$ for cultivated soils. The selected model parameters were here MAT, MAP, $\mathrm{MAT}^{2}, \mathrm{MAP}^{2}$, $\mathrm{MAP} \times$ silt and MAP $\times$ clay. Application of these predictors to our soil $\mathrm{C}$ data gave non-significance regressions $\left(R^{2}=0.33, p=0.36\right)$. None of these six predictors were significant or followed consistent trends for the individual soil orders either, suggesting that climatic variables was less decisive for soil C levels in our regional dataset.

The differences in OM levels of our four soil types are probably related to different factors. First, many Inceptisols from the Database B have not been classified correctly (Mella and Kühne, 1985). Rodríguez (1993) described these soils as Andisols since they exhibit much of the unique andic properties. This is the reason for the Inceptisols large amount of soil C (Fig. 5c). Secondly, the outliers, above the regression line in Fig. 4b coincided with the oldest Andisols. These soils are dated from the last glacial, 20,000 years ago (Besoain, 1985) and exhibited the largest amount of soil C. Although many factors may influence the equilibrium organic $\mathrm{C}$ content at century scale (Sparling et al., 2003), these soils stand the oldest native forest and therefore the largest $\mathrm{C}$ accumulation in the topsoil under long-term undisturbed vegetation. In fact, the highest concentration of $\mathrm{C}$ in the work of Urbina de Alcayaga (1965) was similar to our soils and the soil $\mathrm{C}$ levels did not increased above $0.9 \mathrm{~g} \mathrm{~kg}^{-1}$ of $\mathrm{Al}_{\mathrm{a}}$. Thirdly, poorly drained Andisols were included in our analysis, but most of these soils have been drained for agriculture and there is no (as expected) tendency for these pedons to lie above the regression line. Indeed, many well drained Andisols and Inceptisols showed low organic C content.

Fig. $5 \mathrm{~b}$ reveals an interesting feature, namely that most pedons cluster around the regression line and that deviations mainly are due to 'lacking' soil C relative to $\mathrm{Al}_{\mathrm{a}}$ contents. A careful inspection of the pedons 'lacking' $\mathrm{C}$ show that they are on the west sides, near to the volcanoes or located in the low basin of alluvial plains in the Central Valley. In both cases, the differences amongst soil types suggest that these pedons are really young, as the study area since millions of year experiences numerous eruptions with thick deposition of tephra layers and subsequent alluvial transport and re-deposition of fresh volcanic ash in the flood plains (especially from $40^{\circ} \mathrm{S}$ and south, Fig. 1). This suggests that the soils under the regression line are still not $\mathrm{C}$ saturated, i.e., that our soils have a finite capacity of $\mathrm{C}$ stabilization. However, conclusions on such a maximum $\mathrm{C}$ sorption capacity determined by $\mathrm{Al}$ cannot be drawn firmly from this regional dataset, but requires more analytical studies of soil OM dynamics from selected sites.

\subsection{Organic matter stabilisation by Al and allophane}

We found that amount of soil C $\left(0-20 \mathrm{~cm}, \mathrm{Mg} \mathrm{ha}^{-1}\right)$ was strongly correlated with amount of $\mathrm{Al}$ extractable in acid ammonium acetate within each order and across all soils orders, while the $\mathrm{Al}$ in acetate and un-buffered $\mathrm{KCl}$ extractions did not correlate well with soil $\mathrm{C}$ (Tables 3 and 4). Molar ratios of $\mathrm{Al}$ have been used to interpretation of different $\mathrm{Al}$ pools. In this study $\mathrm{Al}_{\mathrm{k}} /$ $\mathrm{Al}_{\mathrm{a}}$ was $<0.04$, while $\mathrm{Al}_{\mathrm{a}} / \mathrm{Al}_{\mathrm{o}}$ in turn was $<0.03$. The average molar ratio of $\mathrm{C}$ to $\mathrm{Al}_{\mathrm{a}}$ can also provide a measure of degree of Al-saturation of humus. Our regression line between soil $\mathrm{C}$ versus and $\mathrm{Al}_{\mathrm{a}}$ showed that one atom of $\mathrm{Al}$ stabilize 124.6 $( \pm 13.1)$ atoms of $\mathrm{C}$, while in the work of Urbina de Alcayaga (1965) this ratio was much higher $(447 \pm 187)$. The normal molar ratio of soil $\mathrm{C}$ and $\mathrm{Al}$ extracted in pyrophosphate is between 10 and 26 (Percival et al., 2000; GarciaRodeja et al., 2004). These findings suggests that $\mathrm{Al}_{\mathrm{a}}$ extracts a constant, but small fraction of the OMbound forms of $\mathrm{Al}$, which may be used to describe complexation characteristics of the OM. The higher $\mathrm{C} / \mathrm{Al}_{\mathrm{a}}$ ratio relative to $\mathrm{C}$ versus $\mathrm{Al}$ extracted by pyrophosphate may indicate a lower Al saturation of $\mathrm{OM}$ in the former, or may be related to less decomposed $\mathrm{OM}$ being extracted by $\mathrm{Al}_{\mathrm{a}}$ (Zagal et al., 2002).

Un-buffered salts as $\mathrm{LaCl}_{3}$ and $\mathrm{CuCl}_{2}$ are apparently also useful for estimation of $\mathrm{C}$ in $\mathrm{Al}-\mathrm{OM}$ complexes (Garcia-Rodeja et al., 2004). Copper chloride was proposed as a better extractant for Al-humus complexes than pyrophosphate (Kaiser and Zech, 1996). The high efficiency of $\mathrm{CuCl}_{2}$ in extracting $\mathrm{Al}$ has been related to the low $\mathrm{pH}$ of solution (2.7-3.3) and strong complexing power of cations. This reagent may thus be as effective as the acid ammonium ace- 


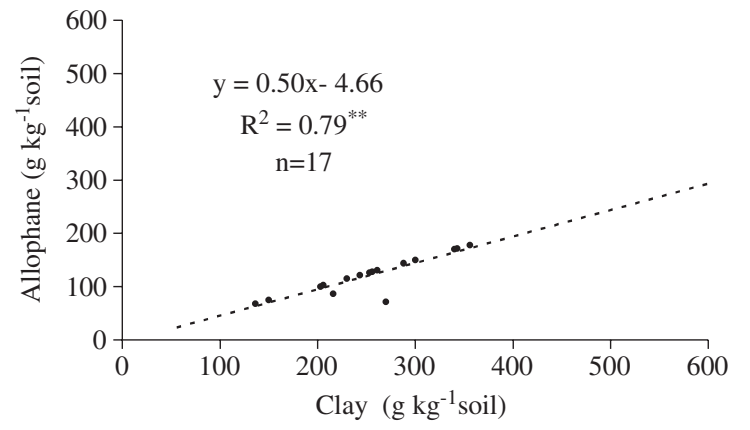

Fig. 6. Relationship between clay content from Database A (Rodríguez, 1993) in volcanic soils of southern Central Chile and content of amorphous material (mainly allophanic) in the same soils compiled from Mella and Kühne (1985). $(* *=P<0.01)$.

tate, because the amounts extracted with $\mathrm{CuCl}_{2}$ (Garcia-Rodeja et al., 2004) are comparable to those of $\mathrm{Al}_{\mathrm{a}}$ in our study. However, more laboratory research is probably needed to verify this.

Andisols with allophanic clay minerals have been reported to correlate with soil $\mathrm{C}$, but this raise the question if the stabilisation is caused by high free $\mathrm{Al}$ content and/or the allophanic materials per se. Parfitt et al. (1999) found by ${ }^{13} \mathrm{C}$-NMR spectroscopy that $\mathrm{Al}$ in monomers or polymeric forms interact with carboxyl groups of OM which may play an important roll for stabilizing soil OM. Also Zunino et al. (1982) found that the turnover of microbial products is slower in allophanic soils than in adjacent alluvial soils. However, on a regional basis, variations of soil $\mathrm{C}$ can be explained by long-term effects other than those found decisive in short-term laboratory studies (Percival et al., 2000). Accordingly, we found that soil $\mathrm{C}$ was strongly correlated with the Al extractable in acid ammonium acetate, although only constituting a few percents of $\mathrm{Al}_{\mathrm{o}}$ (Table 3). A poor relationship was found between soil $\mathrm{C}$ and clay content, but if the content of allophanic material (allophane) influences the soil $\mathrm{C}$ levels could not be revealed by our analysis directly. However, such a comparison was possible on already published data by Mella and Kühne (1985) and Database A. In 17 Chilean soils the allophane content is linear correlated with whole soil content of clay (Fig. 6). As the clay content is poorly correlated with the soil C level, this suggests that acid-extractable Al-forms are more decisive for OM stabilisation than is allophanic material per se. However, as the content of clay versus allophane is not 1 to 1 , but approximately 2 to 1 , the linear regression analysis on the two databases may not be able to distinguish this underlying effect. It is nevertheless consistent with results from Percival et al. (2000) that allophanic material explains less of the of soil $\mathrm{C}$ variations than $\mathrm{Al}$.

\section{Conclusions}

We found that $\mathrm{Al}-\mathrm{OM}$ complexes, rather than clay contents or climatic factors, controls the largest proportion of variation in OM content across volcanic soils in Chile. The clay mineralogy, e.g., the amount of allophanic material, was probably neither decisive for OM levels on this regional scale. These observations are probably related to the genesis of the refractory Al-OM complexes here in southern Central Chile, as soils were formed under the native, acidifying Nothofagus spp. forest previously covering the study area. As the large soil $\mathrm{C}$ pools accumulated under these conditions are still found after 100-200 years of cultivation, the soil $\mathrm{C}$ levels are probably stable under the present-day arable conditions, at least on a century time-scale. This suggests that the Northofagus ecosystem is a very efficient sink for atmospheric $\mathrm{C}$ on a century to millennia-scale.

\section{Acknowledgements}

The authors gratefully acknowledge the help from Dr. Christopher Lusk, Departamento de Botánica, Universidad de Concepción (Chile), Dr. Alexander Neaman, Facultad de Agronomía, Universidad Católica de Valparaíso and the colleagues, Dr. Jorge Retamales, Departamento de Hortofruticultura and Dr. Peter Caligari, Instituto de Biología, Universidad de Talca (Chile), for suggestions and corrections to our manuscript. We also acknowledge the two referees for their useful comments and suggestions on the first version of the manuscript.

\section{References}

Adams, M.L., Hawke, D.J., Nilsson, N.H.S., Powell, K.J., 2000. The relationship between soil solution $\mathrm{pH}$ and $\mathrm{Al}^{3+}$ concentrations in a range of South Island (New Zealand) soils. Aust. J. Soil Res. 38, 141-153. 
Allison, L.E., 1965. Organic carbon. In: Black, C.A., Evans, D.D., Ensminger, L.E., White, J.L., Clark, F.E. (Eds.), Methods of Soil Analysis. Part 2. Chemical and Microbiological Properties. ASA, Madison, Wisconsin, USA, pp. 1372-1376.

Aran, D., Gury, M., Jeanroy, E., 2001. Organo-metallic complexes in an Andosol: a comparative study with a Cambisol and Podzol. Geoderma 99, 65-79.

Besoain, E., 1985. Los suelos. In: Tosso, J. (Ed.), Suelos Volcánicos de Chile. Instituto de Investigaciones Agropecuarias, Chile, pp. $215-256$.

Besoain, E., Sepúlveda, G., 1985. Composición mineralógica de las arcillas $(<2 \mu \mathrm{m})$ de algunas series de suelos volcánicos de la región Central-Sur de Chile. In: Tosso, J. (Ed.), Suelos Volcánicos de Chile. Instituto de Investigaciones Agropecuarias, Chile, pp. 215-256.

Burke, I.C., Yonker, C.M., Parton, W.J., Cole, C.V., Flach, K., Schimel, D.S., 1989. Texture, climate, and cultivation effects on soil organic matter content in U.S. grassland soils. Soil Sci. Soc. Am. J. 53, 800-805.

CIREN (Centro de investigaciones de Recursos Naturales), 2001. Descripciones de Suelo Materiales y Símbolos. Estudio agrológico, X Región, Santiago, Chile, p. 408.

Day, P.R., 1965. Particles fractionation and particles size analysis. In: Black, C.A., Evans, D.D., Ensminger, L.E., White, J.L., Clark, F.E. (Eds.), Methods of Soil Analysis. Part 1. Physical and Mineralogical Properties, Including Statistics of Measurement and Sampling. ASA, Madison, Wisconsin, USA, pp. $545-566$.

DGA (Dirección General de Aguas), 2004. Registro de precipitaciones para la IX y X Región (BNA 200). Departamento de Hidrología, Ministerio de Obras Públicas, Transporte y Telecomunicaciones.

Escudey, M., Föester, J.E., Galindo, G., 2004. Relevance of organic matter in some chemical and physical characteristics of volcanic ash-derived soils. Commun. Soil Sci. Plant Anal. 35, 781-797.

Garcia-Rodeja, E., Nóvoa, J.C., Pentevedra, X., Martinez-Cortizas, A., Buurman, P., 2004. Aluminium fractionation of European volcanic soils by selective dissolution techniques. Catena 56 , $155-183$.

Homman, P.S., Sollins, P., Chapell, H.N., Stangenberger, A.G., 1995. Soil organic carbon in a mountainous, forested region: relation to site characteristics. Soil Sci. Soc. Am. J. 59, 1468-1475.

Kaiser, K., Zech, W., 1996. Defects in estimation of aluminum in humus complexes of podzolic soils by pyrophosphate extraction. Soil Sci. 161, 452-458.

Matus, F.J., Rodríguez, J., 1994. A simple model for estimating the contribution of nitrogen mineralization to the nitrogen supply of crops from a stabilized pool of soil organic matter and recent organic input. Plant Soil 162, 259-271.

McLean, E.O., 1965. Aluminum. In: Black, C.A., Evans, D.D., Ensminger, L.E., White, J.L., Clark, F.E. (Eds.), Methods of Soil Analysis. Part 2. Chemical and Microbiological Properties. ASA, Madison, Wisconsin, USA, pp. 978-998.

Mella, A., Kühne, A., 1985. Sistemática y descripción de las familias, asociaciones y series de los suelos derivados de mate- riales piroclásticos de la zona Central-Sur de Chile. In: Tosso, J. (Ed.), Suelos Volcánicos de Chile. Instituto de Investigaciones Agropecuarias, Chile, pp. 548-716.

Nanzyo, M., Dahlgren, R.A., Shoji, S., 1993a. Chemical characteristics of volcanic ash soils. In: Shoji, S., Nanzyo, M., Dahlgren, R.A. (Eds.), Volcanic Ash Soils. Genesis, Properties and Utilization, Develop. Soil Sci., vol. 21. Elsevier, Amsterdam, pp. $145-187$.

Nanzyo, M., Shoji, S., Dahlgren, R.A., 1993b. Physical characteristics of volcanic ash soils. In: Shoji, S., Nanzyo, M., Dahlgren, R.A. (Eds.), Volcanic Ash Soils. Genesis, Properties and Utilization, Develop. Soil Sci., vol. 21. Elsevier, Amsterdam, pp. 189-207.

ODEPA (Oficina de Estudios y Políticas Agrarias). Estadísticas macrosectoriales y productivas; http.//www.odepa.cl.

Parfitt, R.L., Childs, C.W., 1988. Estimation of form of Fe and Al: a review, and analysis of contrasting soils by dissolution and Moessbauer methods. Aust. J. Soil Res. 26, 121-144.

Parfitt, R.L., Yuan, G., Theng, B.K.G., 1999. A ${ }^{13}$ C-NMR study of the interactions of soil organic matter with aluminium and allophane in podzols. Eur. J. Soil Sci. 50, 695-700.

Parfitt, R.L., Parshotam, A., Salt, G.J., 2002. Carbon turnover in two soils with contrasting mineralogy under long-term maize and pasture. Aust. J. Soil Res. 40, 127-136.

Percival, H.J., Parfitt, R.L., Scott, N.A., 2000. Factors controlling soil carbon levels in New Zealand grassland: is clay content important? Soil Sci. Soc. Am. J. 64, 1623-1630.

Rodríguez, J., 1993. La fertilización de los cultivos. Un método racional. Facultad de Agronomía, Pontificia Universidad Católica de Chile, Chile, p. 291.

Shoji, S., Nanzyo, M., Dahlgren, R.A., 1993. Volcanic Ash SoilsGenesis, Properties and Utilization. Elsevier, Amsterdam.

Soil Survey Laboratory Staff, 1996. Soil Survey Laboratory Methods Manual. Soil Survey Investigations Report, vol. 42. USDASCS, Washington DC.

Sollins, P., Homann, P., Caldwell, C.A., 1996. Stabilization and destabilization of soil organic matter: mechanisms and controls. Geoderma 74, 65-105.

Sparling, G.P., Parfitt, R.L., Hewitt, A.E., Schipper, L.A., 2003. Three possible approaches to define target limits for soil organic matter. J. Environ. Qual. 32, 760-766.

Urbina de Alcayaga, A., 1965. Relaciones entre algunas características físicas y químicas de los suelos derivados de cenizas volcánicas. Agric. Téc. (Chile) 25, 9-18.

Webster, R., Oliver, M.A., 2001. Geostatistics for Environmental Scientists. J. Wiley and Sons, England.

Zagal, E., Rodríguez, N., Vidal, I., Flores, A.B., 2002. Soil organic matter light fraction of volcanic soil under different agricultural managements. Agric. Téc. (Chile) 62, 284-296.

Zunino, H., Borie, F., Aguilera, S., Martin, J.P., Haider, K., 1982. Decomposition of ${ }^{14} \mathrm{C}$-labelled glucose, plant and microbial products and phenols in volcanic ash-derived soils of Chile. Soil Biol. Biochem. 14, 37-43. 